\title{
AOA continuing osteopathic medical education
}

\author{
GEORGE A. REUTHER, MBA
}

Continuing Medical Education, as the term implies, is a lifetime commitment to learning by physicians in the full recognition that the study of medicine doesn't end with graduation from medical school. In 1973, the American Osteopathic Association established the requirement that each member maintain a minimum number of continuing medical education credits during a three-year period in order to continue membership in the association. In addition, 23 states (Table 1) have established minimum CME requirements to qualify for annual relicensure and a number of specialty colleges require a minimum of $\mathrm{CME}$ credits in order to maintain certification.

The AOA activities in CME may be characterized as (1) the approval of general policies and guidelines that provide leadership and a national structure within which CME programs and credit may be recognized, and (2) the maintenance of a computerized CME credit recording and notification mechanism known as Individual Activity Reports (IARs.)

As in the past, experience with the program has led the AOA Board of Trustees and the Committee on Continuing Medical Education to revise certain policies and procedures. Major category changes will be implemented for the coming 3-year cycle in response to the needs of osteopathic physicians across the country. In addition there will be a new emphasis on documenting CME course work in physicians' primary specialties. These changes and a brief history of the program are the focus of this article.

This is the final year of the 1986-88 AOA CME cycle. The AOA CME program has now been in existence for 15 years and four cycles have been completed; the fifth will be completed on Dec 31, 1988.

\section{CME program organization and structure}

The Division of Continuing Medical Education, established in 1973, is a part of the AOA Department of Education and is responsible for implementing the policies of the Board of Trustees and House of Delegates through the Committee on Continuing Medical Education. In administering the guidelines and regulations, the office disseminates in- formation on the CME program to individual physicians and sponsors.

Sponsors may submit programs to the Division for initial approval. Each program is reviewed in accordance with guidelines approved by the Board of Trustees and the Committee and the organization or person is then notified of the hours and category of credit for which the program is approved. As requests for credit are received, the staff reviews the activity and determines eligibility, category, and credit to be granted. Any type of activity not previously considered is referred to the Committee on Continuing Medical Education for a decision.

The AOA maintains an individual computer record for each D.O. and, twice a year, provides each member with a report of his or her activities.

Between the first three-year cycle (1973-76) and

\begin{tabular}{|lcc|}
\hline \multicolumn{3}{|l|}{ TABLE 1: STATES WITH LEGISLATION REQUIRING CME FOR RE- } \\
REGISTRATION OF LICENSE TO PRACTICE MEDICINE.
\end{tabular}




\begin{tabular}{|c|c|c|c|c|}
\hline & $1973-76$ & $1977-79$ & $1980-82$ & $1983-85$ \\
\hline $\begin{array}{l}\text { Number of physicians } \\
\text { with a CME } \\
\text { requirement }\end{array}$ & 9,219 & 10,363 & 12,050 & 11,881 \\
\hline $\begin{array}{l}\text { Number who met } \\
\text { requirement }\end{array}$ & $\begin{array}{l}9,037 \\
(98 \%)\end{array}$ & $\begin{array}{l}10,124 \\
(97.7 \%)\end{array}$ & $\begin{array}{l}11,891 \\
(98.7 \%)\end{array}$ & $\begin{array}{l}11,583 \\
(97.5 \%)\end{array}$ \\
\hline $\begin{array}{l}\text { Number dropped from } \\
\text { membership }\end{array}$ & $\begin{array}{l}182 \\
(2 \%)\end{array}$ & $\begin{array}{r}239 \\
(2.3 \%)\end{array}$ & $\begin{array}{r}159 \\
(1.3 \%)\end{array}$ & $\begin{array}{r}298 \\
(2.5 \%)\end{array}$ \\
\hline
\end{tabular}

the last three year-cycle (1983-85), there had been an overall increase of 2,662 physicians with a CME requirement. This was an increase of $28.8 \%$ over the nine-year period from 1976-1985. This trend is expected to continue.

The pattern is consistent for each three-year cycle with about $98 \%$ of the physician members meeting their $\mathrm{AOA} \mathrm{CME}$ requirement, and about $2 \%$ of those with a requirement potentially being dropped from membership at the conclusion of each cycle. Two percent of the physicians with a requirement equates to about $0.8 \%$ of the overall $\mathrm{AOA}$ membership when adjusted for waivers and exclusion (Table 2).

\section{Trends}

The total number of credit hours recorded has increased significantly each three-year cycle. The greatest number of credits awarded in any one area has been in Category 1-A, formal osteopathic medical programs (Table 3). (Category 1-A-Formal educational programs sponsored by recognized osteopathic institutions, organizations, and their affiliates which meet the quality standards as defined by the AOA.)

The data indicate a steady and constant increase in the number of Category 1-A credits being awarded. Since the first three-year cycle there has been an overall increase of 500,000 category 1 -A credits recorded. This is an increase of $38.5 \%$ over the 12-year period from 1976-1988. This is by far the most utilized of the available categories.

There has also been a continuing growth in the utilization of "other" categories. The other categories include categories 1-B through 1-F and all category 2 credit areas. The use of these other categories has increased during the 12-year period from 1976 through 1988 from 1.2 million to 2.6 million credit hours per three-year cycle. This increase of $1,400,000$ credits represents an increase of $116 \%$. This growth is the result of physicians seeking a variety of means to satisfy their CME obligations.

This growth also reflects AOA policy changes in recent years. It has been and will continue to

\begin{tabular}{|lccccc|}
\hline \multicolumn{5}{|c|}{ TABLE 3. TOTAL CREDITS RECORDED. } \\
\hline \multicolumn{5}{|c|}{ (in millions) } \\
\hline & 1976 & 1979 & 1982 & 1985 & $1988^{*}$ \\
\hline Category 1-A & 1.3 & 1.4 & 1.5 & 1.5 & 1.8 \\
Other & 1.2 & 1.3 & 1.9 & 2.2 & 2.6 \\
\multicolumn{1}{|c|}{ Total } & $\overline{2.5}$ & $\overline{2.7}$ & $\overline{3.4}$ & $\overline{3.7}$ & $\overline{4.4}$ \\
\hline *Projected effective 7/88. & & & & & \\
\hline
\end{tabular}

be useful for physicians and CME sponsors to be knowledgeable of these changes.

It is also interesting to note that the average credit hours actually earned per physician of those meeting their CME requirement has consistently exceeded the base requirement of 150 credit hours (Table 4).

\section{Recent changes in AOA-CME policies}

The major focus of the AOA Board of Trustees and the Committee on Continuing Medical Education during the past 3 years has been on the redesign of the CME program to simplify the recording of CME credits by reducing the number of subcategories from 11 to 4 , and helping to focus attention on the quality and relevancy of course work taken to actual physician practice.

These changes will become effective with the beginning of the next 3-year cycle on Jan 1, 1989.

While physicians still are required to earn a total of 150 credits in the three-year cycle with a minimum 60 credits in category 1 , they may earn the remaining 90 credits in any of the remaining categories. The four newly revised categories (1-A, 1-B, 2-A, and 2-B) are summarized in Table 5.

Another major change to the CME program for the 1989-91 cycle is the requirement that all physicians who are board certified or board eligible must earn a minimum of 50 credits hours or more as may be mandated by the board of their primary specialty in each three-year cycle CME period. These 50 credits may be earned in any combination of categories 1 and 2. Failure to maintain this requirement will result in loss of certification or board eligibility.

\begin{tabular}{|c|c|c|c|c|}
\hline Three-Year Cycle & $1973-76$ & $1977-79$ & $1980-82$ & $1983-85$ \\
\hline $\begin{array}{l}\text { Average credits } \\
\text { earned per physician } \\
\text { completing his/her } \\
\text { CME requirements }\end{array}$ & 277 & 267 & 286 & 319 \\
\hline
\end{tabular}


AOA members serving in the military will be exempt from the 50 credit hours in their specialty requirement when assigned to positions other than their specialty.

Also, beginning Jan 1, 1989, life members and honorary life members will no longer be exempt from the AOA CME program.

These changes appear in the new AOA CME guide (1989-1991) that will be mailed to members in December 1988. The guide will be of major interest to all members and to sponsors of CME programs.

\section{CME division activities}

The Division of Continuing Medical Education is seeking to identify additional ways in which to serve the membership. It is seeking additional sources of CME programs for physicians who are limited by time or geographic location or both. The focus for this work is in the area of audiovisual programs and computer interactive programs. A catalog of sources of educational programs is being prepared for distribution in early 1989 . (The category 1 sponsors recognized by the AOA is given in Table 6.)

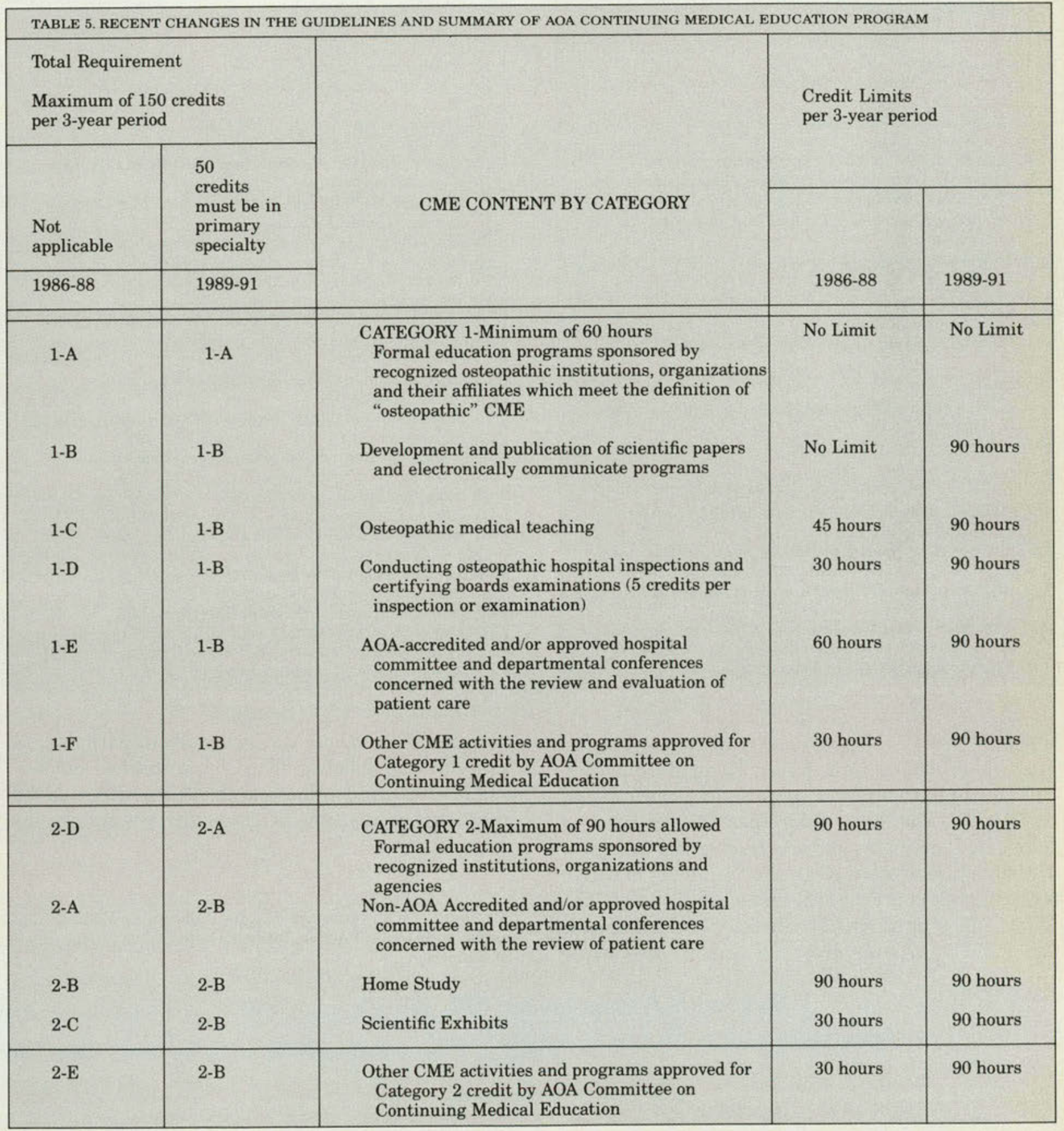


TABLE 6. CATEGORY 1 SPONSORS RECOGNIZED BY THE AOA.

\section{Divisional societies}

1. Arizona Osteopathic Medical Association

2. Eastern Regional Osteopathic Convention

3. Iowa Osteopathic Medical Association

4. Kentucky Osteopathic Association

5. Maine Osteopathic Association

6. Michigan Center for Continuing Education in Osteopathic Medicine

7. Missouri Osteopathic Association

8. New England Osteopathic Assembly

9. Ohio Osteopathic Association

10. Osteopathic Physicians and Surgeons of California

11. Pennsylvania Osteopathic Medical Association

12. Texas Osteopathic Medical Association

13. Washington Osteopathic Medical Association

14. West Virginia Society of Osteopathic Medicine

\section{Practice affiliates}

1. American Academy of Osteopathy

2. American College of Osteopathic Internists

3. American College of Osteopathic Obstetricians and Gynecologists

4. American College of Osteopathic Surgeons

5. American Osteopathic Academy of Sclerotherapy, Inc.

6. American Osteopathic College of Radiology

7. American Osteopathic College of Allergy and Immunology

8. American Osteopathic College of Anesthesiologists

9. Midwest Osteopathic Society of Anesthesiologists

\section{Osteopathic foundations}

1. Colorado Springs Osteopathic Foundation

\section{Military}

1. Navy Health and Sciences Education and Training

Colleges of Osteopathic Medicine

1. Chicago College of Osteopathic Medicine

2. College of Osteopathic Medicine of Oklahoma State University

3. College of Osteopathic Medicine of the Pacific

4. Kirksville College of Osteopathic Medicine

5. Michigan State University College of Osteopathic Medicine

6. New York College of Osteopathic Medicine

7. Ohio University College of Osteopathic Medicine

8. Philadelphia College of Osteopathic Medicine

\section{Conclusions}

The Committee on Continuing Medical Education will continue to study, evaluate, and recommend revisions to the AOA guidelines. The number of recognized programs and recorded credit will grow in the next few years as greater numbers of osteopathic physicians graduate and enter practice. The AOA CME program will be directed toward awarding credit in a wide diversity of activities while
9. Southeastern College of Osteopathic Medicine

10. Texas College of Osteopathic Medicine

11. University of Health Sciences/College of Osteopathic Medicine

12. University of Medicine and Dentistry of New Jersey/ School of Osteopathic Medicine

13. University of New England/College of Osteopathic Medicine

14. University of Osteopathic Medicine and Health Sciences/College of Osteopathic Medicine

15. West Virginia School of Osteopathic Medicine

\section{Osteopathic hospitals}

1. Botsford General Hospital/Farmington Hills, MI

2. Carson City Osteopathic Hospital/Carson City, MI

3. Charles E. Still Osteopathic Hospital/Jefferson City, MO

4. Community General Osteopathic Hospital/Harrisburg, PA

5. Community Hospital of Lancaster/Lancaster, PA

6. Des Moines General Hospital/Des Moines, IA

7. Detroit Osteopathic Hospital/Detroit, MI

8. Doctors Hospital/Columbus, $\mathrm{OH}$

9. Fort Worth Osteopathic Hospital/Fort Worth, TX

10. Garden City Osteopathic Hospital/Garden City, MI

11. Grandview Hospital/Dayton, $\mathrm{OH}$

12. Jacksonville Medical Center/Jacksonville, FL

13. Lansing General Hospital/Lansing, MI

14. Massapequa General Hospital/Seaford, NY

15. Memorial Osteopathic Hospital/York, PA

16. Metropolitan Hospital/Grand Rapids, MI

17. Metropolitan Hospital/Dallas, TX

18. Metropolitan Hospital/Central Division, Parkview Division, and Springfield Division, Philadelphia, PA

19. Michiana Osteopathic Community Hospital/ Southbend, IN

20. Michigan Osteopathic Medical Center/Detroit, MI

21. Oklahoma Osteopathic Hospital/Tulsa, OK

22. Pacific Hospital of Long Beach/Long Beach, CA

23. Parklane Medical Center/Kansas City, MO

24. Parkview Hospital/Toledo, $\mathrm{OH}$

25. Phelps County Regional Medical Center/Rolla, MO

26. Phoenix General Hospital and Medical Center/ Phoenix, AZ

27. Pontiac Osteopathic Hospital/Pontiac, MI

28. Riverside Hospital/Wilmington, DE

29. Suburban General Hospital/Norristown, PA

30. Sun Coast Osteopathic Hospital/Largo, FL

31. Traverse City Osteopathic Hospital/Traverse City, MI

32. Warren General Hospital/Warren, $\mathrm{OH}$

remaining primarily concerned about patient care and clinical education. The Committee on Continuing Medical Education and the AOA office may be contacted at any time to assist with your questions or concerns.

Mr. Reuther is the assistant director, Continuing Medical Education and Hospital Accreditation Divisions, AOA Department of Education. 


\section{APPENDICES}

\section{APPENDIX I}

Membership of AOA Committees on Osteopathic Education 1988-1989

\section{DEPARTMENT OF EDUCATION}

\section{Chairman: Ronald A. Esper, DO}

\section{Bureau of Professional Education}

Chairman: Alvin D. Dubin, DO; member-at-large

Vice-chairman: Joseph J. Namey, DO; educator

Daniel H. Belsky, DO; COPT

Howard Collier, LLD; public representative

Harry B. Elmets, DO; Advisory Board

Myron S. Magen, DO; Committee on Colleges

Robert E. Mancini, DO; National Board of Osteopathic Medical Examiners

Richard Millard, $\mathrm{PhD}$; public representative

Eugene A. Oliveri, DO; residency/preceptorship

Michael I. Opipari, DO; intern training

Jay E. Sandelin; public representative

Paul Grayson Smith, Jr, DO; continuing medical education

Fred C. Tinning, PhD; AACOM

Secretary: W. Douglas Ward, $\mathrm{PhD}$, director, AOA Department of Education

\section{Committee on Colleges}

Chairman: Myron S. Magen, DO; AACOM

Vice-chairman: Joseph J. Namey, DO; member-at-large

J. Leonard Azneer, PhD; AACOM

A. Archie Feinstein, DO; member-at-large

Ronald Goldberg, DO; member-at-large

Samson A. Inwald, DO; member-at-large

Frank W. Myers, DO; AACOM

David M. Richards, DO; AACOM

Harold Thomas, DO; member-at-large

Secretary: W. Douglas Ward, PhD, director, AOA Department of Education

Council on Osteopathic Educational Development

Chairman: David M. Richards, DO; AACOM

Vice-chairman: Mr. Jay E. Sandelin; public representative

Carl R. Vann, $\mathrm{PhD}$; higher education community representative

Secretary: W. Douglas Ward, PhD, director, AOA Department of Education

\section{Committee on Postdoctoral Training}

Chairman: Daniel H. Belsky, DO; member-at-large

Vice-chairman: Eugene A. Oliveri, DO; member-atlarge

James D. Alexander, DO; C-preventive medicine James D. Bernard, DO; C-dermatology

Barbara J. Briner, DO; AAO

Patricia Anne Cottrille, DO; C-pediatrics

Milton J. Dakovich, DO; director of medical education Joseph A. Dieterle, DO; C-pediatrics

Richard R. DiPietro, DO; C-radiology

Joseph M. Dubin, DO; C-general practice

Clare W. Elliott, DO; C-surgery

Allan R. Fox, DO; C-pathology

Kenneth P. Glinter, DO; C-obstetrics/gynecology

Robert L. Hambrick, DO; C-emergency medicine

J. James Jerele, Jr, DO; C-nuclear medicine

Charles J. Kaczey, DO; C-neuropsychiatry

Robert E. Kappler, DO; AAO

Joseph V. Koehler, DO; C-internal medicine

A.A. Mannarelli, DO; C-anesthesiology

Michael K. Murphy, DO; military

Neil A. Natkow, DO; C-general practice

Carlton M. Noll, DO; C-proctology

Michael I. Opipari, DO; AACOM

Ray E. Piper, DO; C-general practice

Vance D. Powell, DO; director of medical education

B.B. Slaughter, DO; AOHA

Henry Sonenshein, DO;C-ophthalmology/otorhinolaryngology

Donald F. Stanton, DO; C-rehabilitation medicine

Ralph J. Tomei, DO; C-internal medicine

Frank M. Weaver, DO; C-obstetrics/gynecology

Daniel Wisely, DO; C-surgery

Bernard Irwin Zeliger, DO; C-orthopedic surgery

Secretary: W. Douglas Ward, PhD, director, AOA Department of Education

a. Subcommittee on Intern Training

Vice-chairman: Michael I. Opipari, DO (3-1989); AACOM

Patricia Anne Cottrille, DO; pediatrics

Joseph M. Dubin, DO; C-general practice

Robert E. Kappler, DO; AAO

Joseph V. Koehler, DO; C-internal medicine

Michael K. Murphy, DO; military

Ray E. Piper, DO; C-general practice

Vance D. Powell, DO; director of medical education

B.B. Slaughter, DO; AOHA

Frank M. Weaver, DO; C-obstetrics/gynecology 
Daniel Lee Wisely, DO; C-surgery

Secretary: W. Douglas Ward, $\mathrm{PhD}$, director, AOA Department of Education

b. Subcommittee on Residency/Osteopathic, Residency/ Non-osteopathic and Preceptorship Training

Vice-chairman: Eugene A. Oliveri, DO; member-atlarge

James T. Alexander, DO; C-preventive medicine

James D. Bernard, DO; C-dermatology

Barbara J. Briner, DO; AAO

Milton J. Dakovich, DO; director of medical education

Joseph A. Dieterle, DO; C-pediatrics

Richard R. DiPietro, DO; C-radiology

Clare W. Elliott, DO; C-surgery

Allan R. Fox, DO; C-pathology

Kenneth P. Glinter, DO; C-obstetrics/gynecology

Robert L. Hambrick, DO; C-emergency medicine

J. James Jerele, Jr, DO; C-nuclear medicine

Charles J. Kaczey, DO; C-neuropsychiatry

A.A. Mannarelli, DO; C-anesthesiology

Michael K. Murphy, DO; military

Neil A. Natkow, DO; C-general practice

Carlton M. Noll, DO; C-proctology

B.B. Slaughter, DO; AOHA

Henry Sonenshein, DO; C-ophthalmology/otorhinolaryngology

Donald F. Stanton, DO; C-rehabilitation medicine

Ralph J. Tomei, DO; C-internal medicine

Bernard Irwin Zeliger, DO; C-orthopedic surgery

Secretary: W. Douglas Ward, $\mathrm{PhD}$, director, AOA Department of Education
3. Committee on Continuing Medical Education

Chairman: Paul Grayson Smith, DO; House of Delegates

Vice-chairman: T. Eugene Zachary,DO; House of Delegates

Dorothy E. Carnegie, DO; practice affiliates

Perry M. Dworkin, DO; C-practice affiliates

Robert J. George, DO; C-practice affiliates

Mr Jeff Heatherington; AOSED

Tad B. Jacobs, DO; small states

Richard R. Jeffries, DO; military liaison

Marc Morganstine, DO; AODME

James R. Stookey, DO; AACOM

Secretary: Ms Delores Rodgers, AOA Department of Education

4. Advisory Board for Osteopathic Specialists

Chairman: Harry B. Elmets, DO; member-at-large

Vice-chairwoman: Dorothy E. Carnegie, DO; member-atlarge

Daniel H. Belsky, DO; Bureau of Professional Education

Eugene A. Oliveri, DO; Bureau of Professional Education

(Plus representatives from each of the 18 certifying boards)

Secretary: W. Douglas Ward, PhD, director, AOA Department of Education 


\section{@arnation. introduces}

\section{THE FIRST HYPOALLERGENIC FORMULA MADE FROM HYDROLYZED WHEY PROTEIN}

Because of increasingly recognized sensitivity to soy, ${ }^{1}$ Carnation has developed Carnation ${ }_{\circledast}$ GOOD START H.A. ${ }^{\mathrm{TM}}$ It effectively resolves symptoms in infants suffering from formula intolerance or milk allergy, and may prevent allergic manifestations in infants with a family history of allergy.

When atopic infants were fed the GOOD START H.A. formulation, four clinical studies showed a $0 \%$ reaction rate, ${ }^{2-5}$ and one study showed a $3.6 \%$ reaction rate. ${ }^{6}$

No curd formation and rapid gastric emptying, make GOOD START H.A. easy to digest and may cause less spitting up. The whey base makes it a high-quality protein source for optimal growth. And, parents will like the pleasant taste and aroma, as well as the competitive price for long-term use. GOOD START H.A. is available in easy-to-dissolve powder in 12-oz. cans.

The GOOD START H.A. formulation has been thoroughly researched in clinical trials and safely fed to more than 25,000 infants over the past 3 years in Europe. 


\section{INSTEAD OF SOY, RECOMMEND GOOD START H.A. FOR:}

\section{Formula Intolerance}

Resolves symptoms of milk allergy or intolerance such as spitting up, skin rash, runny nose, and colic

\section{Routine Feeding of Atopic Infants}

May prevent allergic manifestations in infants with a family history of allergy ${ }^{2}$

\section{Routine Feeding of Normal Infants}

Nutritionally complete for optimal growth and development

\footnotetext{
References:

1. Committee on Nutrition, American Academy of Pediatrics: Pediatric Nutrition Handbook, ed 2, Forbes GB, Woodruff CW (eds). Elk Grove Village, Ill, American Academy of Pediatrics, 1985, p 210.

2. Vandenplas Y, Deneyer M, Sacre L, et al: Preliminary data on a field study with a new hypo-allergic formula. Eur J Pediatr, to be published.

3. Kahn A, Rebuffat E, Blum D, et al: Difficulty in initiating and maintaining sleep associated with cow's milk allergy in infants. Sleep 1987;10:116-121.

4. Zabransky S, Zabransky M: Preliminary clinical experience with a hypoallergenic infant formula. Extracta Paediatrica 1987;11:10-22.

5. Schmidt E, Reinhardt D, Gerke R: The use of hypoallergenic milk formulas in newborns. Der Kinderarzt 1987:5:627-631.

6. Denis R, Willème D: Data on file, Carnation Co.
}

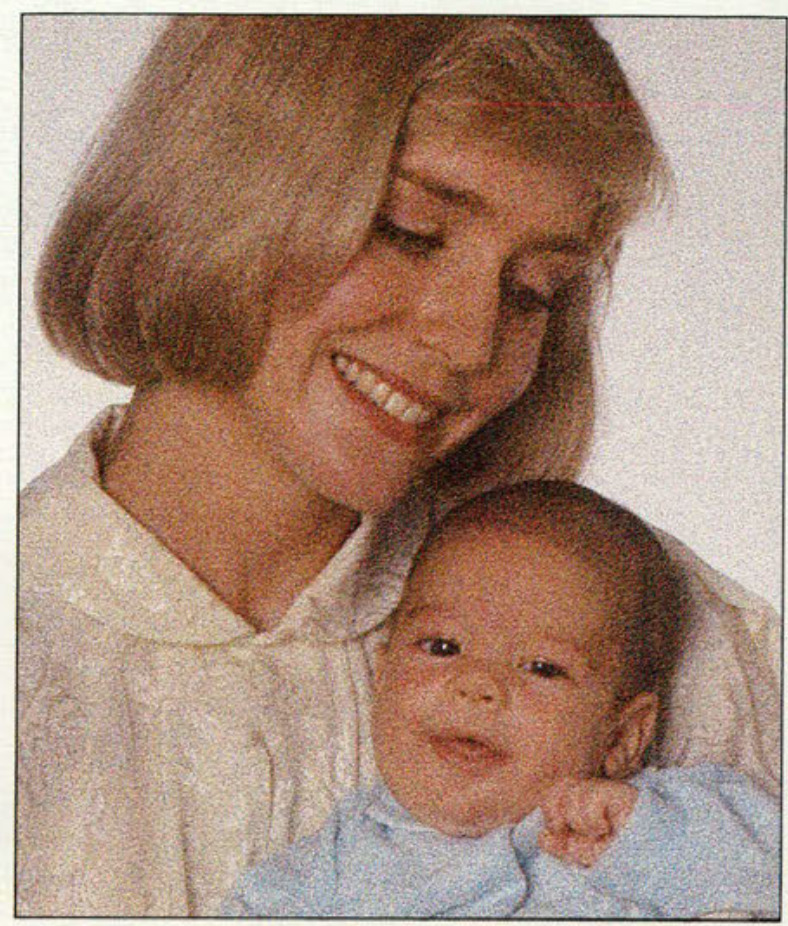

COMPLETE NUTRITIONAL INFORMATION INGREDIENTS: $42 \%$ ENZYMATICALLY HYDROLYZED REDUCED MINERALS WHEY AND WHEY PROTEIN CONCEN. TRATE, 24\% VEGETABLE OILS (PALM OLEIN, HIGH-OLEIC SAFFLOWER AND COCONUT), $17 \%$ MALTODEXTRIN, $14 \%$ LACTOSE, $1 \%$ LECITHIN, AND LESS THAN $1 \%$ OF EACH OF THE FOLLOWING: CALCIUM CHLORIDE, POTASSIUM CHLORIDE, POTASSIUM CITRATE, CALCIUM PHOSPHATE, CHOLINE BITARTRATE, SODIUM ASCORBATE (VITAMIN C), SALT, MAGNESIUM CHLORIDE, TAURINE, FERROUS SULFATE (IRON), INOSITOL, ZINC SULFATE, L-CARNITINE, ALPHA TOCOPHERYL ACETATE (VITAMIN E), NIACINAMIDE, CALCIUM PANTOTHENATE, COPPER SULFATE, RIBOFLAVIN, VITAMIN A ACETATE, PYRIDOXINE HYDROCHLORIDE (VITAMIN B6), THIAMINE MONONITRATE, FOLIC ACID, PHYLLOQUINONE (VITAMIN K), POTASSIUM IODIDE, VITAMIND3, MANGANESE SULFATE, BIOTIN, VITAMIN B12.

NOTE: CONTAINS LACTOSE.

Call toll-free 1-800-628-BABY (2229) to request samples,

or for more information write to:

Carnation Nutritional Products 5045 Wilshire Blvd, Los Angeles, CA 90036.

\begin{tabular}{|c|c|c|c|c|c|c|}
\hline $\begin{array}{l}5 \mathrm{fl} \mathrm{oz} \text { Provides } 100 \text { Calories, } \\
\text { Prepared As Directed }\end{array}$ & $\begin{array}{l}\text { Per } 10 \\
\text { Calori }\end{array}$ & & $\begin{array}{c}\text { Caloric } \\
\text { Distribution }\end{array}$ & & \multicolumn{2}{|c|}{$\begin{array}{l}\text { Per } 100 \\
\text { Calories } \\
\end{array}$} \\
\hline $\begin{array}{l}\text { NUTRIENTS: } \\
\text { PROTEIN }\end{array}$ & 2.4 & $\mathrm{~g}$ & $9.8 \%$ & $\begin{array}{l}\text { VITAMIN C } \\
\text { (Ascorbic Acid) }\end{array}$ & 8 & $\mathrm{mg}$ \\
\hline FAT & 5.1 & $\mathrm{~g}$ & $46.0 \%$ & CHOLINE & 12 & $\mathrm{mg}$ \\
\hline CARBOHYDRATE & 11 & g & $44.2 \%$ & INOSITOL & 6.1 & $\mathrm{mg}$ \\
\hline WATER & 135 & g & & MINERALS: & & \\
\hline LINOLEIC ACID & 450 & $\mathrm{mg}$ & & CALCIUM & 64 & $\mathrm{mg}$ \\
\hline VITAMINS: & & & & PHOSPHORUS & 36 & $\mathrm{mg}$ \\
\hline VITAMIN A & 300 & IU & & MAGNESIUM & 6.7 & $\mathrm{mg}$ \\
\hline VITAMIN D & 60 & IU & & IRON & 1.5 & $\mathrm{mg}^{*}$ \\
\hline VITAMIN E & 1.2 & IU & & ZINC & 0.75 & $5 \mathrm{mg}$ \\
\hline VITAMIN K & 8.2 & $\mathrm{mcg}$ & & MANGANESE & 7 & $\mathrm{mcg}$ \\
\hline THIAMINE (Vitamin B1) & 60 & $\mathrm{mcg}$ & & COPPER & 80 & $\mathrm{mcg}$ \\
\hline RIBOFLAVIN (Vitamin B2) & 135 & $\mathrm{mcg}$ & & IODINE & 8 & $\mathrm{mcg}$ \\
\hline VITAMIN B6 & 75 & $\mathrm{mcg}$ & & SODIUM & 24 & $\mathrm{mg}$ \\
\hline VITAMIN B12 & 0.22 & $\mathrm{mcg}$ & & POTASSIUM & 98 & $\mathrm{mg}$ \\
\hline NIACIN & 750 & $\mathrm{mcg}$ & & CHLORIDE & 59 & $\mathrm{mg}$ \\
\hline FOLIC ACID (Folacin) & 9 & mcg & & OTHERS: & & \\
\hline PANTOTHENIC ACID & 450 & $\mathrm{mcg}$ & & L-CARNITINE & 10 & $\mathrm{mg} / \mathrm{qt}$ \\
\hline BIOTIN & 2.2 & mcg & & TAURINE & 50 & $\mathrm{mg} / \mathrm{qt}$ \\
\hline
\end{tabular}

*The addition of iron to this formula conforms to the recommendation of the Committee on Nutrition of the American Academy of Pediatrics.

\section{@arnation.}

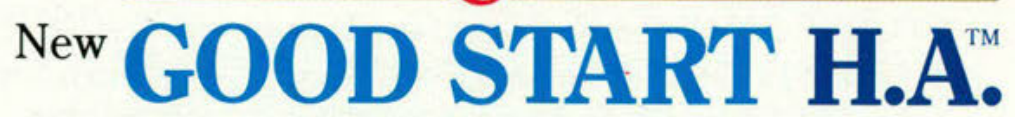

Hypoallergenic Infant Formula 


\section{APPENDIX II}

Colleges of Osteopathic Medicine

$\begin{array}{ll}\text { Established } & \begin{array}{l}\text { Year of } \\ \text { Last Survey }\end{array}\end{array}$

Year of

California

College of Osteopathic Medicine of the Pacific (COMP)

1977

1987

1992

Florida

Southeastern College of Osteopathic Medicine (SECOM)

1981

1985

1990

Illinois

Chicago College of Osteopathic Medicine (CCOM)

1900

1988

1993

Iowa

University of Osteopathic Medicine and Health Sciences

College of Osteopathic Medicine and Surgery (UOMHS/COMS)

1898

1986

1991

Maine

University of New England College of Osteopathic Medicine

(UNECOM)

1976

1983

1990

Michigan

Michigan State University-College of Osteopathic Medicine

(MSU/COM)

1964

1983

1989

Missouri

University of Health Sciences College of Osteopathic Medi-

cine (UHS/COM)

1916

1987

1992

Kirksville College of Osteopathic Medicine (KCOM)

1892

1985

1990

New Jersey

University of Medicine and Dentistry of New Jersey-School

of Osteopathic Medicine (UMDNJ/SOM)

1976

1986

1991

New York

New York College of Osteopathic Medicine of New York Institute of Technology (NYCOM)

1977

1986

1991

Ohio

Ohio University College of Osteopathic Medicine (OUCOM)

1975

1987

1992

Oklahoma

Oklahoma University College of Osteopathic Medicine (OUCOM)

1972

1988

1993

Pennsylvania

Philadelphia College of Osteopathic Medicine (PCOM)

1898

1986

1991

Texas

Texas College of Osteopathic Medicine (TCOM)

1966

1985

1990

West Virginia

West Virginia School of Osteopathic Medicine (WVSOM)

1974

1988

1993 